\title{
LÍNGUA PORTUGUESA COMO SEGUNDA LÍNGUA PARA SURDOS: PROCEDIMENTOS DA COERÊNCIA NA REESCRITA DO TEXTO
}

\author{
Claudio Manoel de Carvalho Correia (UFS) \\ Mônica de Gois Silva Barbosa (UFS) \\ Alzenira Aquino de Oliveira (UFS)
}

Resumo: A sociedade se defronta continuamente com inúmeras situações nas quais a escrita da língua está presente e tem relevância. Para o sujeito surdo, o texto escrito constitui uma ferramenta de comunicação entre ele e os ouvintes. Na busca de alternativas para o ensino da Língua Portuguesa para surdos, muitas questões têm exigido atenção de pesquisadores e algumas interferências podem ser evitadas se trabalhadas preventivamente. Pensando nisso, professores da Universidade Federal de Sergipe - UFS - desenvolveram o curso de extensão: Ensino de Língua Portuguesa para surdos. Esse curso foi uma proposta efetiva de ensino do português como segunda língua para surdos, considerando a LIBRAS como primeira língua dessa comunidade. Com base nisso e tomando como objeto de estudo a escrita da Língua Portuguesa, analisa-se, neste artigo, seis textos produzidos por três alunos surdos com nível médio concluído. Foi avaliado se a intervenção pedagógica possibilitou, na reescrita dos textos, um melhor desenvolvimento dos procedimentos de coerência de acordo com Costa Val (2006). Para sua fundamentação, o presente estudo apoia-se nos pressupostos teóricos da Linguística a partir das abordagens de Antunes (2005); Brochado (2003); Costa Val (2006); Faria (2001); Fávero e Koch (2008); Koch (2009); Marcuschi (2008) e Salles (2004). De maneira geral, verificou-se que, após o curso de extensão, a reescrita das produções conseguiu contemplar com mais propriedade os critérios de coerência elencados por Costa Val (2006) e permitiu aos textos uma melhor compreensão de sentido.

Palavras-chave: Coerência; Escrita; Surdez.

Abstract: Society is continually faced with innumerable situations in which language writing is present and relevant. For the deaf person, the written text constitutes a tool of communication between him and the listeners. In the search of alternatives for the teaching of the 
Portuguese language for deafs, many questions have required the attention of researchers and some interferences can be avoided if worked preventively. Thinking about this, professors from the Federal University of Sergipe - UFS - developed the extension course: Teaching Portuguese language for the deaf. This course was an effective proposal for teaching Portuguese as a second language for the deaf, considering LIBRAS as the first language of this community. Based on this and taking as a study object the writing of the Portuguese language, this article analyzes six texts produced by three deaf students with a finished average level. It was evaluated if the pedagogical intervention made possible, in the rewriting of the texts, a better development of coherence procedures according to Costa Val (2006). For its foundation, the present study is based on the theoretical assumptions of Linguistics based on the approaches of Antunes (2005); Brochado (2003); Costa Val (2006); Faria (2001); Fávero and Koch (2008); Koch (2009); Marcuschi (2008) and Salles (2004). In general, it was verified that after the extension course, the rewriting of the productions was able to better contemplate the criteria of coherence listed by Costa Val (2006) and allowed the texts a better understanding of meaning.

Keywords: Coherence; Writing; Deafness.

\section{INTRODUÇÃO}

A dificuldade apresentada pelos alunos surdos durante o curso de graduação Licenciatura em Letras Libras da Universidade Federal de Sergipe - UFS, quanto ao domínio da leitura e escrita da língua portuguesa tornou-se uma preocupação para os professores deste curso. Constatavase, cotidianamente, que o processo de desenvolvimento da escrita dos surdos que utilizam a Língua Brasileira de Sinais - LIBRAS - como sua primeira língua e a Língua Portuguesa - LP - como segunda língua apresentava singularidades que necessitavam ser observadas, analisadas e que estes alunos 
precisavam de auxílio e apoio para que pudessem dar conta de suas atividades acadêmicas. Além disso, precisavam ampliar a prática de leitura e escrita para atingirem o domínio da língua portuguesa na modalidade escrita.

Com a intenção de contribuir com as pesquisas e as práticas no ensino de língua portuguesa para surdos, apresentaremos aqui o relato de uma experiência realizada na UFS com os discentes surdos. Trata-se de uma contribuição singela, considerando o universo de pesquisadores e profissionais que atuam na educação dos surdos com ampla experiência. Mas, sincera, no desejo de colaborar com o aprendizado e desenvolvimento dos discentes surdos como pessoa, dentro dos limites impostos pelo contexto em que atuamos no desempenho de nossa função social de professores universitários responsáveis pela formação de profissionais para o ensino de língua que integrarão as comunidades acadêmicas do nosso país.

Nesse sentido, no semestre 2017.1, ofertamos um curso de extensão intitulado Língua Portuguesa para Pessoas com Surdez, com o objetivo de oferecer aos alunos o contato com textos da língua portuguesa sempre respeitando o fato singular de que para os surdos o português é uma segunda língua e a modalidade à qual têm acesso é apenas a escrita, sendo a Língua Brasileira de Sinais - LIBRAS - sua primeira língua. 
Assim, utilizamos metodologias que atraíssem o interesse dos alunos visando a envolvê-los ativamente no processo de ensino-aprendizagem, aproximando-os da língua portuguesa na modalidade escrita e incentivando-os também à produção de textos, sendo esta uma atividade primordial na vida acadêmica e na qual os alunos surdos da UFS têm demonstrado muita dificuldade.

Convém ressaltar que não é objetivo deste artigo investigar os processos de aquisição de língua e linguagem por crianças surdas ou ouvintes, muito menos as práticas pedagógicas no ensino da língua portuguesa no processo educacional dos surdos. Além disso, é pertinente salientar que não discorreremos também sobre os conceitos de língua, linguagem, língua materna, primeira língua, segunda língua e língua estrangeira.

O nosso propósito aqui é relatar uma experiência que contribuiu para o desenvolvimento da leitura e escrita da língua portuguesa dos discentes surdos na vida acadêmica. Faremos apenas um breve epítome sobre a língua portuguesa para pessoas com surdez, no sentido de destacar a relevância do contato com a língua portuguesa escrita para enriquecimento do vocabulário desse público e a importância de uma abordagem dialógica em sala de aula, 
onde o professor faz interferências, orientações, promove discussão sobre o objeto do conhecimento estudado, no caso, a língua portuguesa, promovendo assim modificações diante da ação de aprender e ensinar.

\section{A LÍNGUA PORTUGUESA PARA PESSOAS SURDAS}

Conforme evidencia a literatura sobre a escrita de surdos (BARBOSA, 2011; SAMPAIO, 2007; QUADROS, 2006: SALLES 2004; BROCHADO, 2003; FARIA, 2001, entre outros), as pessoas com surdez - crianças, jovens e adultos desenvolvem a escrita da LP de forma diversificada, quando comparada à escrita de um ouvinte. Tais estudos apresentam que a Língua Brasileira de Sinais - LIBRAS - interfere diretamente na aprendizagem da Língua Portuguesa - LP - e, consequentemente, revela-se na sua forma escrita. Também as pesquisas evidenciam que o fato das diferentes modalidades de uso da LIBRAS (gestual-visual) e da LP (oralauditiva) por si só já implicam estratégias diferentes para o domínio linguístico de cada língua.

Há harmonia entre as pesquisas existentes na área de que o processo de aprendizagem da Língua Portuguesa se diferencia entre surdos e ouvintes brasileiros. "As razões dessa afirmação estão relacionadas com o processo de aquisição dessa língua, considerando a condição física das pessoas surdas: são surdas" (QUADROS, 1997, p.67). Segundo 
Salles et al (2004), o aspecto mais flagrante na aquisição de uma língua oral como L2 pela criança surda é que ela deve adquirir propriedades no nível fonológico e prosódico, para os quais seu aparato sensorial auditivo está impedido (ou parcialmente impedido) de apreender. O que resta à criança ou pessoa surda - independente da idade de aquisição - é o acesso à representação gráfica dessas propriedades, no caso, a modalidade escrita da língua portuguesa.

Ainda de acordo com Salles et al,

a formulação de estratégias de exposição do surdo ao input da língua portuguesa deve ser guiada pelo pressuposto de que a aquisição de L2 consiste na representação mental dos estágios sucessivos do conhecimento linguístico, a interlíngua, em que se manifestam princípios da Gramática Universal, com opções paramétricas fixadas. O sucesso da aquisição da língua portuguesa (ou qualquer língua oral) por surdos depende de que sejam consideradas essas variáveis, por um lado, e as diferenças cruciais nas modalidades oral-auditiva e vísuo-espacial, por outro. As pesquisas têm demonstrado, que apesar do acesso extremamente restrito aos dados linguísticos na língua oral, o aprendiz surdo desenvolve habilidades linguísticas na língua oral, havendo muitos que atingem um conhecimento bastante aproximado ao de aprendizes ouvintes de L2, ou seja, conseguem absorver o input necessário para aprender a língua alvo. (2004, p.78) 
O termo segunda língua (L2) utilizado neste trabalho faz referência a qualquer língua que é aprendida subsequentemente à língua materna (L1) e não se restringe apenas às línguas estrangeiras aprendidas em consequência de uma vivência exterior ou outras necessidades pessoais; remete genericamente a qualquer língua estrangeira, inclusive àquelas que aprendemos por meio de educação formal em sala de aula, caso do aprendizado da língua portuguesa pela comunidade surda no Brasil.

Considerando que as teorias se desenvolvem a partir de conjecturas e hipóteses a respeito dos fenômenos observados, havendo sempre a possibilidade de que novas descobertas surjam, exigindo assim reformulações e, por vezes, mudanças de paradigmas, abordaremos uma proposição sobre o desenvolvimento do processo de escrita da língua portuguesa por pessoas surdas como um procedimento que pode ser construído por meio de atividades desenvolvidas em sala de aula. Tais práticas são associadas cumulativamente com as experiências vivenciadas pelos próprios alunos, envolvendo situações comunicativas como possibilidades de uso da L2 (língua portuguesa na modalidade escrita) enquanto objeto social e interacional, proporcionando assim acesso constante a essa língua. 
Não há dúvida de que, ao produzir textos com processos inadequados, não há possibilidade de fornecer condições de acesso ao leitor. Por isso, este não terá um entendimento consensual a respeito da leitura e do sentido que dela se tem. De certa forma, refletir sobre o que apresenta no enunciado não é simplesmente obter conhecimentos objetivos, é um aspecto efetivado na interação do texto com o leitor.

Identifica-se que a prática de leitura é um ato social que se interliga com a cultura do indivíduo escritor, por isso se crê serem possíveis posicionamentos diferenciados quanto à produção do sentido: um deles é ir além do que está no texto por meio de inferências sustentadas na leitura de mundo. Neste sentido, Marcuschi diz que

o texto é uma proposta de sentido e se acha aberto a várias alternativas de compreensão. Mas todo cuidado aqui é pouco, pois o texto não é uma caixinha de surpresas ou algum tipo de caixa preta. Se assim fosse, ninguém se entenderia e viveríamos em eterna confusão. Há, pois, limites para a compreensão textual. Nessa visão, a coerência de um texto é uma perspectiva interpretativa do leitor e não se acha inscrita de forma completa e unívoca do texto. Um texto pode ter coerências diversas e, ao carecer de evidências o leitor constrói a sua. $(2008$, p.242)

A partir das considerações feitas, este trabalho se fundamentará no seguinte conceito de texto: “O texto não 
é simplesmente um artefato linguístico, mas um evento que ocorre na forma de linguagem inserida em contextos comunicativos" (MARCUSCHI, 2008, p.75-76). Especificando, Fávero e Koch asseguram:

$O$ texto consiste em qualquer passagem, falada ou escrita, que forma um todo significativo, independente de sua extensão. Trata-se, pois, de uma unidade de sentido, de um continuo comunicativo contextual que se caracteriza por um conjunto de relações responsáveis pela tessitura do texto - os critérios ou padrões de textualidade, entre os quais merecem destaque especial a coesão e a coerência. (1998, p.25)

Esses conjuntos de relações, denominados critérios de textualidade, são importantes para a produção de sentido do texto. Beaugrande e Dressler, em 1981, postularam a existência de sete princípios constitutivos da textualidade. Dois deles (coesão e coerência) são orientados para o texto e cinco (intencionalidade, aceitabilidade, informatividade, situacionalidade e intertextualidade) são centrados no usuário.

Segundo Costa Val (2006), a textualidade representa o conjunto de características que tornam um texto realmente texto e não apenas uma sequência de frases. A autora ainda afirma que a coesão e a coerência estão relacionadas com 
o material conceitual e linguístico de um texto, enquanto que os outros cinco critérios, que se centram no usuário, são fatores pragmáticos envolvidos no processo sociocomunicativo.

A partir desse ponto de vista, será exposta, a seguir, uma breve explicação sobre o princípio da coerência, com o intuito de melhor compreendê-la como um dos critérios constitutivos da textualidade.

\section{COERÊNCIA}

É importante ressaltar aqui alguns esclarecimentos sobre a diferença entre coesão e coerência. As noções desses dois princípios sofreram alterações com o decorrer do tempo. Hoje, defende-se que o conceito de ambos é diferente, não se podendo confundi-los e que a presença da coesão não é determinante para a coerência. No entanto, não se pode fazer uma distinção radical entre elas, visto que, para analisar os elementos coesivos, pode-se, em alguns momentos, recorrer a elementos contextuais de ordem sociocognitiva e interacional, mergulhando-se, assim, no campo da coerência (KOCH, 2004).

Ao refletir sobre tal relação, Antunes assegura que as relações entre a coesão e a coerência são bastante estreitas e interdependentes. Quer dizer, não há uma coesão que exista por si 
mesma e para si mesma. A coesão é uma decorrência da própria continuidade exigida pelo texto, a qual, por sua vez, é exigência da unidade que dá coerência ao texto. (2005, p.177)

Assim sendo, a coesão está interligada à coerência. Por isso, os elementos coesivos presentes em um texto o tornam interpretável. Entretanto, a ausência dos elementos de coesão não impossibilita a coerência.

A coerência, segundo Beaugrande e Dressler (Apud MARCUSCHI, 2008, p.121), "diz respeito ao modo como os componentes do universo textual, ou seja, os conceitos e relações subjacentes ao texto de superfície são mutuamente acessíveis e relevantes entre si, entrando numa configuração veiculada de sentidos".

É o aspecto responsável pelo sentido do texto, envolvendo fatores lógico-semânticos e cognitivos. Assim sendo, a interpretação de um texto depende do conhecimento partilhado entre os interlocutores. Sobre isso, afirma Marcuschi:

A coerência é em boa parte uma atividade realizada pelo receptor de um texto que atua sobre a proposta do autor. E, nesse afã, o receptor segue as pistas (deixadas pelo autor nas operações de coesão textual) como primeiros indicadores interpretativos. De todo modo, a coerência é uma atividade 
interpretativa e não uma propriedade imanente ao texto. Liga-se, pois a atividades cognitivas e não ao código apenas. (2008, p.121)

Corroborando as ideias acima, Koch frisa que

a coerência, portanto, longe de constituir mera qualidade ou propriedade do texto, é o resultado de uma construção feita pelos interlocutores, numa situação de interação dada, pela atuação conjunta de uma serie de fatores de ordem cognitiva, situacional, sociocultural e intencional. (2009, p.52)

De acordo com os autores, para compreender a coerência de um texto, é necessário ultrapassar os limites dos aspectos linguísticos, visto que existem outros fatores que interagem no texto, tais como conhecimentos de mundo, enciclopédicos, culturais. Sobre isso, Fávero (1999, p.60) afirma que "o texto contém mais do que o sentido das expressões na superfície textual, pois deve incorporar conhecimentos e experiências cotidianas, atitudes e intenções, isto é, fatores não linguísticos". Portanto, esses conhecimentos que determinam a construção da coerência não são dados a partir do conhecimento da língua, mas, sim, do conhecimento cultural. Por isso, Antunes (2005, p.176) admite que a coerência é linguística, mas também extralinguística, pragmática, pois também depende de fatores que não são aqueles internos à língua. 
Alguns autores têm determinado alguns critérios para analisar como se constitui a coerência no texto.

Koch (2009) enumera cinco níveis nos quais a coerência se estabelece: sintático semântico, temático, estilístico e ilocucional. E Koch e Travaglia (2001) afirmam que a coerência é resultado de uma relação conjunta de uma série de fatores de ordem cognitiva, situacional, sociocultural e interacional.

Já Costa Val (2006) retoma Charolles (1978), que estabelece como requisitos para coesão e coerência a repetição, a progressão, a não contradição e a relação. Essas quatro "metarregras" são denominadas por Costa Val de continuidade, progressão, não contradição e articulação.

Continuidade: No desenvolvimento do discurso se faz necessário retomar elementos para que exista coerência. Faz-se necessária a unidade, a conservação de elementos permanentes. Como afirma Costa Val (2006): “Uma seqüência que trate a cada passo de um assunto diferente certamente não será aceita como texto" e ainda garante que "Quanto a coerência, esse requisito se manifesta pela retomada de conceitos, de idéias" (p.21).

Portanto, segundo a autora, avaliar esse critério em um texto é verificar se há informações conceituais que percorrem em todo o seu desenvolvimento, garantindo-lhe unidade. 
Progressão: Esse segundo critério diz respeito à retomada do conceito sem se limitar a simplesmente repetir a ideia. Faz-se necessário o surgimento de novas informações sobre o que foi retomado. Como afirma Costa Val,

o texto deve retomar seus elementos conceituais e formais, mas não pode se limitar a essa repetição. É preciso que apresente novas informações a propósito dos elementos retomados. São esses acréscimos semânticos que fazem o sentido do texto progredir e que, afinal, o justificam. (2006, p.23)

Portanto, esse critério se faz pelo acréscimo de novos comentários a um mesmo tópico.

Não contradição: Esse requisito se refere a apresentações de informações no texto sem elementos contraditórios. Esse critério "deve ser observado tanto no âmbito interno quanto no âmbito das relações do texto com o mundo a que se refere" (COSTA VAL, 2006, p.24-25).

A autora ainda assegura que, para um texto ser internamente coerente, precisa, primeiramente, respeitar princípios lógicos elementares, ou seja, não se pode contradizer. Além disso, o texto também não pode se contradizer ao mundo a que se alude: "o mundo textual tem que ser compatível com o mundo que o texto representa" (COSTA VAL, 2006, p.25). 
Articulação: Diz respeito ao encadeamento dos fatos no texto, ou seja, como se organizam. Sobre esse critério, a autora elucida:

Com ele estarei me referindo à maneira como os fatos e conceitos apresentados no texto se encadeiam, como se organizam, que papeis exercem uns com relação aos outros. Avaliar a articulação das idéias de um texto, para mim, significa verificar se elas têm a ver umas com as outras e que tipo especifico de relação se estabelece entre elas (além das relações de continuidade, progressão e não contradição, já coberta pelas outras condições de coerência) (COSTA VAL, 2006, p.27-28)

Assim, a articulação diz respeito ao tipo de relação que as ideias, as informações estabelecem entre si. Nesse caso, dois aspectos devem ser observados: "a presença e a pertinência das relações entre os fatos e conceitos apresentados" (COSTA VAL, 2006, p.28).

Em confronto com essa perspectiva, foi desenvolvida uma intervenção pedagógica através do curso de extensão de Língua Portuguesa para surdos. Foram ministradas as aulas à luz da abordagem aqui defendida.

\section{ASPECTOS METODOLÓGICOS}

Constituição do corpus: foram analisadas seis redações de três estudantes surdos, com nível médio concluído. 
A amostra pesquisada corresponde a cinquenta por cento das redações dos alunos que realizaram a atividade de reescrita.

Sujeitos da pesquisa: surdos bilíngues, usuários da Libras, com nível médio concluído. Alguns participantes cursando o nível superior.

\section{Detalhamento do curso de extensão}

Uma ação de extensão do tipo curso com carga horária de 45 (quarenta e cinco) horas presenciais foi cadastrada no Sistema Integrado de Gestão Acadêmica - SIGAA - da UFS, intitulada como LÍNGUA PORTUGUESA PARA PESSOAS COM SURDEZ e executada durante o período de 2017.1, em turno contrário ao que os alunos estavam matriculados em disciplinas obrigatórias. Com um total de 15 (quinze) alunos inscritos, dentre os quais, 09 (nove) participaram de forma integral e concluíram com o percentual mínimo de frequência de $75 \%$, conforme exigência da comissão organizadora do curso.

No primeiro dia de aula, após explanação dos objetivos da proposta de extensão, foi apresentado um questionário escrito em língua portuguesa referente aos dados pessoais de cada aluno e, logo após, amplamente discutidas as experiências de cada um no tocante ao aprendizado da LP em seu processo educacional, momento em que os próprios 
alunos relataram grande dificuldade na leitura e escrita nessa língua, posicionando-se como sendo sua segunda língua e a LIBRAS sua primeira língua.

Foi solicitada, nesse primeiro encontro, uma atividade de escrita de um texto com o tema: "Enem 2017 terá opção integralmente traduzida em libras para estudantes surdos" corpus da pesquisa. Inicialmente foram dadas instruções que o texto deveria ser dissertativo e não houve delimitação de quantidade mínima ou máxima de linhas.

Nas aulas subsequentes, foram abordados os seguintes temas:

- Estrutura e interpretação de texto em LP;

- Produção de texto de texto em LP com ênfase na pontuação;

- Produção de texto de texto em LP com ênfase nas figuras de linguagens;

- Leitura de texto em LP com imagens e em libras;

- Contação da história do texto;

- As metáforas e seu uso na LP;

- Vocabulário contextualizado da LP;

- Escrita e reescrita de texto.

No que concerne ao detalhamento das atividades desenvolvidas em cada aula, nos concentraremos naquelas que tiveram como temática a escrita e reescrita de textos em língua portuguesa. 
Os procedimentos adotados para as atividades de leitura, escrita e reescrita seguiram os critérios sugeridos por Faria (2005, Programa surdo- educador). O texto argumentativodissertativo foi o escolhido para o desenvolvimento da atividade.

A primeira aula se deteve a realizar reflexões iniciais sobre gêneros textuais, breve explanação sobre estilo próprio de alguns gêneros.

A segunda aula se voltou para explicação do texto dissertativo argumentativo. Explicou-se a forma, a organização e a função do gênero em questão.

$\mathrm{Na}$ terceira aula, seguimos o passo a passo abaixo discriminado:

\section{Apresentação de imagens relacionadas ao texto:}

Foi apresentada aos alunos a imagem de uma sala de aula com alunos e professor. Em seguida, foi feita uma explanação sobre a leitura da imagem.

2. Trabalho do vocabulário (palavras-chave) em língua de sinais, Língua Portuguesa escrita e digitada com o alfabeto datilológico da língua de sinais:

Nessa ocasião, os alunos tiveram a oportunidade de explanar a sua compreensão sobre a imagem apresentada. Após todos darem sua opinião, foram trabalhadas as palavras-chave em língua de sinais (sinal e alfabeto datilológico) e em LP escrita. 
3. Contação da estória, em língua de sinais, equivalente ao texto a ser lido:

Nesse momento, o professor realizou a contação do texto em língua de sinais.

4. Distribuição do texto para leitura com os olhos - sem sinais e sem oralidade:

Nessa quarta etapa, os alunos receberam um texto em LP para leitura com os olhos.

5. Destaque para as palavras desconhecidas, trabalhando significados e contextualização através da LIBRAS e escrita em LP:

Após a leitura do texto, os alunos destacaram as palavras desconhecidas. Foi trabalhado o significado de maneira contextualizada através da Libras e da LP.

6. Diálogo professor-aluno, em língua de sinais sobre a interpretação do texto:

Foi feita uma interpretação coletiva do texto e, em seguida, realizou-se um debate sobre "O desafio de ser professor nos dias atuais".

7. "Recontação" da estória pelos alunos:

A cada aluno foi dada a oportunidade de recontar o texto.

Na quarta aula, o professor deu continuidade às etapas abaixo: 
8. Leitura completa do texto escrito em Língua Portuguesa:

Nesse momento, cada aluno fez novamente a leitura do texto escrito.

\section{Escrita individual sobre o entendimento do texto:}

Após o desenvolvimento das oito etapas citadas acima, foi solicitada a seguinte atividade aos alunos: "Elabore um texto dissertativo-argumentativo com o seguinte tema: O DESAFIO DE SER PROFESSOR NOS DIAS ATUAIS"

Após a elaboração dos textos, o professor fez a análise das produções e, na quinta aula, foram realizadas as atividades seguintes:

\section{Debate em grupos sobre os textos produzidos:}

Nesse momento, os alunos tiveram a oportunidade de analisar individualmente seus textos com as orientações individuais da professora. Foram feitas observações em relação à forma, ao conteúdo e aos aspectos formais da língua.

\section{Escrita de um novo texto.}

Nesse momento, os alunos reescreveram seus textos após as orientações dadas individualmente.

Na última aula do curso, após as atividades de intervenção, 
foi solicitada a reescrita do texto referente à primeira atividade do curso; cada aluno teve acesso ao seu texto original e em seguida foram orientados a reescrevê-lo com a mesma temática: “Enem 2017 terá opção integralmente traduzida em libras para estudantes surdos" (corpus desta análise). Foram dadas as mesmas instruções: texto dissertativo sem delimitação de quantidade mínima ou máxima de linhas.

\section{ANÁLISE DOS CRITÉRIOS DE COERÊNCIA}

Neste tópico serão analisados os critérios de coerência elencados por Costa Val (2006). Tem-se a intenção de averiguar se a reescrita dos textos, após a intervenção pedagógica, contemplou um melhor desenvolvimento dos quatro procedimentos de coerência: continuidade, progressão, não contradição e articulação.

Portanto, não interessa apenas constatar se há ou não o emprego desses critérios, mas, sim, verificar de que forma estudantes surdos com nível médio concluído constroem e reconstroem seus textos. Além disso, nos interessa verificar como são empregados tais elementos em uma produção de segunda língua, que carrega marcas da transferência da LIBRAS. 


\section{CONTINUIDADE}

\section{Aluno 1 (A1)}

O texto elaborado pelo aluno A1 foi desenvolvido em oito linhas e com apresentação de ideias desconectadas, sem recursos linguísticos que caracterizem a continuidade conceitual.

\begin{tabular}{|l|}
\hline o Enem 2017 para alunos com pessoas surdas no brasil \\
\hline que fazer inserção de enem, obrigatório de interprete \\
\hline de libras no video de libras que a prova de \\
\hline enem em libras ou português que os alunos surdos \\
\hline na sala que o participante sendo necessita o \\
\hline recurso de libras, um intérprete precisa ajuda \\
\hline os alunos surdo durante a prova de enem, eles \\
\hline perguntam a duvida de palavra no enem é muito dificil. \\
\hline
\end{tabular}

Constatamos que, após a intervenção, o Aluno A1 apresenta um texto reescrito com dezenove linhas distribuídas em três parágrafos, com a presença de elementos linguísticos no decorrer do discurso que permitem uma sequência lógica de ideias. No segundo parágrafo o Aluno A1 reescreveu: "professores e mec se reuniram e organizaram o enem e ministério da educação divulgou nova regra enem em libras..." . Verifica-se que o requisito da continuidade se manifesta com retomada de conceitos e ideias.

Portanto, comparando a primeira produção do aluno A1 com a segunda produção solicitada através da atividade de reescrita, há um desenvolvimento com mais propriedade do critério da continuidade. 


\section{Aluno 2 (A2)}

$\mathrm{O}$ aluno $\mathrm{A} 2$, ao redigir seu primeiro texto, desenvolve-o em apenas três linhas:

\section{Recurso muitos dos surdos todos treinar}

Enem em libras necessitar a video impor-

tante integral surdos.

Nesse caso, em relação ao critério da continuidade, não há retomada de elementos conceituais, de ideia, pois existem apenas a exposição de uma ideia, sem seu desenvolvimento, sem sua retomada, sem continuidade conceitual.

Após a intervenção, foi verificado que o aluno A2 já conseguiu desenvolver esse critério nos dois parágrafos do texto reescrito. No primeiro parágrafo o aluno traz a ideia que o Enem é difícil para o surdo, escrever texto é difícil: "Enem difícil", "surdos não saber". No segundo parágrafo o aluno A2 faz retomada de elementos possibilitando a coerência: "... futuro Enem ter adaptadas, vídeo em libras necessitar importância". Percebe-se a unidade, a conservação da ideia necessária no critério da continuidade. Assim, em relação à continuidade, o aluno, mesmo que tenha desenvolvido um texto em dez linhas, conseguiu contemplar a unidade do texto com a retomada de conceito.

\section{Aluno 3 (A3)}

Em relaçãoa esse critério, o aluno $A 3$ consegue desenvolver, porém de maneira limitada, em apenas dois parágrafos. 
A3 traz a seguinte ideia: as dificuldades enfrentadas pelo surdo no processo seletivo do Enem: "No passado os surdos não entenderem tema de redação, disciplina também não conhecerem as palas alguns no Enem, é muito difícil...". No segundo parágrafo, há a continuidade no plano conceitual. As dificuldades, hoje, estão sendo sanadas: "Hoje já começa ter traduzido o vídeo no enem e capaz pode na inscrição o Enem que querem traduzir libras do vídeo no enem..."

Portanto, na reescrita do texto, o aluno A3 avança em relação ao emprego desse critério. Seu texto foi desenvolvido em quatro parágrafos, conseguindo contemplar a unidade através da retomada de elementos no decorrer do discurso. Há uma sequência que trata do mesmo assunto. No primeiro parágrafo, A3 explica que, no passado, os alunos não entendiam a prova, reprovavam, tinham dificuldade:

\begin{tabular}{|l|}
\hline O passado os surdos lerem uns textos, mas \\
\hline não entenderam, não conhecerem alguns palavras \\
\hline uns disciplina, é muita dificuldade que tem mui- \\
\hline to problemas. Eles reprovaram muito que o co- \\
\hline mo uns textos não têm contexto \\
\hline
\end{tabular}

Esse plano conceitual é mantido nos outros três parágrafos. O parágrafo dois esclarece que os intérpretes não podiam ajudar por cumprimento a regras: ... "os intérpretes não poderam os surdos, porque tem lista a regra no MEC...". No parágrafo três, esclarece que as dificuldades diminuíram 
com a prova em Libras: "Hoje tem o video língua de sinais da prova no Enem. Eles se observem as provas de vídeo...". Finaliza o último parágrafo ainda com a unidade temática: A dificuldade no Enem diminuiu com a prova em vídeo: "Como eles observem umas provas que capaz conseguirem, depois gostam de video...".

Portanto, nos quatro parágrafos, há continuidade do tema. Além disso, comparando a primeira produção do aluno A3 com a segunda produção solicitada através da atividade de reescrita, há um desenvolvimento com mais propriedade do critério da continuidade.

\section{PROGRESSÃO}

\section{Aluno 1 (A1)}

No primeiro texto construído por $\mathrm{A} 1$, não há registro de mecanismos de retomada de elementos semânticos, apenas uma exposição de ideias desordenadas sem construção de sentido e sem estruturação em parágrafos, prevalecendo a ausência de novas informações conectadas com o próprio texto. Há uma lacuna de registros semânticos, que, quando inseridos no texto, produzem a construção de sentido e progressão justificando as ideias apresentadas.

$\mathrm{Na}$ análise da reescrita de $\mathrm{A} 1$, podemos verificar um avanço neste critério de progressão iniciado pela própria 
estruturação do texto em três parágrafos. O Aluno A1, em seu primeiro parágrafo, apresenta a temática de seu texto "o enem 2017 para pessoas surdas e com deficiencia auditiva no brasil" e progride no segundo parágrafo, fazendo um desenvolvimento da ideia apresentada, inclusive com argumentação "questões de enem traduzir em língua de sinais durante a prova é melhor".

Assim, registramos um avanço significativo do critério progressão na reescrita do texto apresentada pelo aluno A1.

\section{Aluno 2 (A2)}

Como observado no critério anterior, o texto produzido pelo aluno 2 limitou-se a três linhas, não sendo possível, portanto, verificar a progressão do texto. Não há a presença de informações novas. Entretanto, na produção de reescrita, há um avanço. No primeiro parágrafo, A2 traz a ideia de que o Enem é difícil, não consegue escrever a redação. No segundo parágrafo, há uma progressão da ideia, com a informação de que futuramente o Enem terá provas em vídeo Libras, facilitando a compreensão da prova. Portanto, A2 não repetiu a ideia, trouxe nova informação, como podemos verificar:

\begin{tabular}{|l|}
\hline \multicolumn{1}{|c|}{ O Enem difícil mais ouvintes alguns provas } \\
\hline regras todo sabendo ouvintes mas surdos não \\
\hline saber que explicam não pode ética intrepretes \\
\hline tema de texto simples esse ler necessário \\
\hline Fazer escritos não consegui. \\
\hline
\end{tabular}




\begin{tabular}{|l|}
\hline \multicolumn{2}{|c|}{ No Recurso precisam treinar surdos arrumar } \\
\hline escritos relação, futuro Enem ter adaptadas, \\
\hline vídeo em libas necessitar importância dentro \\
\hline Interpretação lugar sala ter obedecemos o videos \\
\hline Felicidade tudo provas fácil muito Ótimo. \\
\hline
\end{tabular}

Portanto, analisando a primeira produção de três linhas e essa segunda produção, solicitada após o curso de extensão, percebemos o desenvolvimento do critério da progressão na reescrita do aluno $\mathrm{A} 2$.

\section{Aluno A3 (A3)}

Em relação a esse critério, o aluno 3 conseguiu estabelecer a progressão nas duas produções, porém, na atividade de reescrita do seu texto, A3 traz uma progressão mais detalhada. Ou seja, não há apenas uma informação nova, mas ideias novas que surgiram ao longo do texto.

A primeira produção A3 inicia trazendo a ideia das dificuldades enfrentadas no Enem por surdos. No segundo parágrafo, há a soma da ideia nova à anterior quando o aluno informa que hoje o Enem é disponibilizado em vídeo com tradução dos textos em libras. Assim, há o critério da progressão em seu texto, pois uma nova informação foi somada a ideia anterior.

Entretanto, na reescrita, o aluno avança e consegue apresentar, na produção de reescrita, três informações novas acrescentadas à anterior. Há um bom desenvolvimento do critério progressão em seu texto. 
No primeiro parágrafo, o aluno informa que, no passado, no processo seletivo do Enem, os surdos sentiam dificuldade no entendimento dos textos escritos da prova: "O passado os surdos lerem uns textos, mas não entederam, não conheceram alguns palavras uns disciplinas". No parágrafo dois, há a seguinte ideia nova: Os intérpretes não 0 Libras, facilitando o entendimento da prova. Por fim, no último parágrafo, A3 acrescenta a ideia de que, com essa facilidade, os surdos se sentem estimulados a estudar e tentar o Enem.

Portanto, percebe-se o critério da progressão ao longo de todo o texto e um desenvolvimento mais aprofundado do critério progressão na segunda produção.

\section{NÃO CONTRADIÇÃO}

\section{Aluno 1 (A1)}

No primeiro texto de A1, a lógica discursiva está ausente, pois apenas ideias soltas são apresentadas, sem qualquer vínculo, seja de coerência ou contradição, tendo em vista que o texto elaborado não estabelece um sistema próprio de encadeamento de fatos ou conceitos que permitam a constituição de conteúdo proposicional determinado pelo próprio texto.

Entretanto, o critério da não contradição aparece no texto reescrito por A1 quando se manifesta linguisticamente 
pelo emprego de tempos e aspectos verbais instaurando um sistema próprio de situação dos fatos por ele abordados: "os surdos reprovam" referindo-se às dificuldades dos textos em língua portuguesa nas provas do Enem e "surdos passam no enem" fazendo alusão à tradução das provas para Libras.

Desse modo, o critério da não contradição foi contemplado após a intervenção das aulas de língua portuguesa, registrando-se uma evolução na construção da reescrita, na qual se veiculam mecanismos conceituais específicos adequados à estrutura lógico-semântica do texto.

\section{Aluno 2 (A2)}

Ao desenvolver o textoem três linhas, oaluno não contradiz, mas desenvolve sua produção sem contextualização. Em contrapartida, no segundo texto, A2 apresenta a ideia e a desenvolve sem se contradizer. As informações dos dois parágrafos respeitam princípios lógicos elementares. Além disso, a produção textual também não se contradiz ao mundo a que se refere: o texto traz a ideia de que o Enem é difícil para os surdos, mas a adaptação da prova traduzida em Libras facilita.

\section{Aluno 3 (A3)}

O aluno 3 desenvolveu esse requisito da não contradição nos dois textos, porém a produção de reescrita, por ter sido 
desenvolvida em quatro parágrafos, totalizando 18 linhas, contemplou de maneira significativa esse critério. No texto de reescrita, o aluno afirma as dificuldades dos surdos no processo seletivo do Enem, acrescenta a ideia do vídeo que agora é disponibilizado e o quanto isso facilitou e estimulou os candidatos surdos a concorrerem. Portanto, suas ocorrências não se contradizem, são compatíveis entre si. Além disso, o texto também não se contradiz com o mundo que ele representa.

Comparando as duas produções escritas do aluno 3, percebemos um melhor desenvolvimento do emprego dos tempos e aspectos verbais na reescrita: "os surdos... não entenderam, não conheceram. Eles reprovaram...". Assim, apesar do primeiro texto do aluno contemplar esse critério, foi observada, na segunda produção, uma frequência maior de elementos coesivos, possibilitando um melhor desdobramento do texto sem contradição.

\section{ARTICULAÇÃO}

\section{Aluno 1 (A1)}

No que concerne ao quarto e último quesito de coerência considerado nesta análise, no primeiro texto do Aluno A1, o que ocorre é uma difusão de palavras e ideias desarticuladas, sem relação explícita entre si, causando embaraços à leitura. 
Quando analisamos o texto da reescrita, verificamos a ocorrência de construção de sentido significativo no discurso apresentado e a articulação entre as ideias expostas pelo autor, além da presença e pertinência das relações entre os fatos e conceitos abordados. "surdos reprovam"... "surdos criticam o mec"... "professores e mec se reuniram e organizaram o enem"... " traduzir em língua de sinais durante a prova melhor"... "e surdos passam no enem".

A propósito do critério analisado, verificamos o fato de que o Aluno A1 apresenta, no texto reescrito, registros de conhecimentos de construção textual que foram assimilados durante a intervenção e que permitiram a utilização pertinente de recursos e mecanismos linguísticos para resolver as questões que causaram embaraços à leitura do primeiro texto.

\section{Aluno 2 (A2)}

Em relação a esse critério, podemos afirmar que o primeiro texto produzido por A2 não apresenta desenvolvimento de ideias articuladas. Há apenas apresentação de uma informação de maneira solta. Como não existem ideias, mas, sim, uma única ideia exposta de maneira vaga, há ausência do critério articulação.

Contudo, na sua produção de reescrita, esse critério é apresentado no plano lógico-semântico, mesmo com 
a ausência de mecanismos linguísticos formais, como por exemplo, conjunção, advérbios temporais, etc. Pelo desenvolvimento das ideias e sua progressão, há articulação entre as ideias apresentadas nos dois parágrafos: o Enem com prova em língua portuguesa escrita é difícil para o surdo, mas o Enem com prova traduzida em Libras é mais fácil para o surdo. Portanto, no segundo texto, há uma relação entre as ideias, e, assim, percebe-se que, com a intervenção, o aluno conseguiu contemplar esse critério em sua produção textual.

\section{Aluno 3 (A3)}

Esse critério foi contemplado no primeiro texto de A3. Constata-se isso através do emprego de elementos coesivos: Lê-se no primeiro parágrafo "No passado os surdos não entenderem" e no segundo parágrafo: "Hoje já começa ter traduzido vídeo no Enem". Percebe-se uma articulação das ideias e a presença de outros recursos coesivos ao longo do texto.

Contudo, na produção de reescrita, esse critério foi desenvolvido com mais propriedade. Há utilização de um número maior de elementos coesivos, bem como a articulação das ideias também foi desenvolvida com mais profundidade.

No primeiro parágrafo, A3 utiliza o termo "o passado", a conjunção adversativa "mas". Há a presença de elementos 
anafóricos: "O passado os surdos lerem uns textos, mas não entederam, não conheceram alguns palavras uns disciplinas" (...) "Eles reprovam muito que o como uns textos não têm contextos."

No parágrafo três, a articulação com os fatos do texto se dá pelo plano lógico-semântico e pelo conectivo "hoje":

Hoje tem o vídeo língua de sinais da prova no Enem. Eles se observem as provas de vídeo língua de sinais e observam desenvolver e adaptada língua de sinais que entendem.

Por fim, A3 estabelece relação pertinente das informações do último parágrafo com o conjunto do texto. Portanto, como vimos, o aluno 3 teve um avanço significativo após a proposta de intervenção.

\section{CONSIDERAÇÕES FINAIS}

A produção escrita de surdos é um campo de pesquisa que vem crescendo no âmbito nacional. Diante disso, este trabalho traz resultados que podem contribuir com informações que possibilitem uma reflexão sobre o ensino de LP para surdos e um repensar sobre a produção escrita de surdos bilíngues.

Diante da relevância do assunto e supondo a interferência da LIBRAS na produção escrita da LP, procurou-se, através da análise das seis produções escritas, verificar se os 
critérios da coerência elencadas por Costa Val (2006) estavam contemplados nas produções e se a proposta de intervenção, através do curso de extensão, possibilitou um desenvolvimento mais preciso dos critérios de coerência.

A partir das análises, constatou-se que, em relação ao critério da continuidade, progressão e articulação, das três primeiras produções, apenas uma produção tinha, de maneira razoável, esses dois critérios. Após a intervenção, os três textos reescritos contemplaram esses recursos. Em relação a não contradição presente no texto, a produção do aluno 1 não contemplava; o texto do aluno 2 não se contradizia, porém seu texto não tinha contextualização. A produção do aluno 3 não apresentava contradição, contudo seu texto não tinha muito aprofundamento de ideias. Comparando com as produções de reescrita, foi constatado que os três textos contemplaram esse critério.

Portanto, após a proposta de intervenção, a coerência dos textos reescritos se deu através dos procedimentos de continuidade, progressão, não contradição e articulação. Percebeu-se que alguns conectores ausentes foram subentendidos e interpretados pela relação das ideias dos textos. Nessas produções, a ausência de alguns conectivos coesivos foi gerada pela interferência da LIBRAS. Os elementos de coesão não são simples elementos sintáticos, 
pois compõem formas de imprimir sentido. Sua ausência, porém, não impossibilita a textualidade (MARCUSCHI, 2008).

Os surdos precisam estar em um espaço que possibilite sua formação bilíngue: tendo o direito de aprender a LIBRAS como primeira língua e a LP com metodologia adequada. Isso possibilitaria aos estudantes surdos um maior conhecimento em $L P$, resultando em uma escrita com maior nível de coerência. Portanto, ao avaliar um texto escrito de um aluno surdo, deve-se levar em consideração que a LP é sua segunda língua. Diante disso, deve-se deixar claro que, na produção escrita do surdo, há uma forma peculiar de produzir sentido e expressar suas ideias, visto que indivíduos bilíngues, ao vivenciarem uma situação de interação na segunda língua, nunca desativam totalmente a primeira língua.

Diante desta experiência, podemos constatar que, da mesma forma que acontece para ouvintes, o conhecimento prévio e a familiaridade com vocabulário e recursos da língua transmitem segurança com o que vão escrever. Por isso, nesse momento, é imprescindível o contato com a língua portuguesa escrita, para ajudá-las no processo de transferência daquilo que elas sinalizam quanto ao que querem escrever. $O$ que cabe nesse momento não se refere às cobranças do português padrão e distante, mas à organização das ideias no papel. A língua ganha força e sentido, uma vez que pode ser compartilhada. 
Espera-se que o professor que tenha posse dessas análises reflita sobre sua prática de ensino, repense sua metodologia em sala de aula e reveja seus critérios de avaliação da produção escrita dos surdos.

\section{REFERÊNCIAS}

ANTUNES, Irandé (2005). Lutar com palavras: coesão e coerência. São Paulo: Parábola Editorial.

BARBOSA, Monica de Gois Silva (2011). O mecanismo da coerência na produção escrita dos surdos. Foco no vestibular 2011 da UFS. (Dissertação - Mestrado em Letras) - UFS.

BROCHADO, Sônia Maria Dechandt (2006). "A apropriação da escrita por crianças surdas". In Estudos Surdos I. Petrópolis-RJ: Arara Azul.

COSTA VAL, Maria da Graça (2006). Redação e textualidade. 3.ed. São Paulo: Martins Fontes.

FARIA, Sandra Patrícia de (2001). "Interface da Língua Brasileira de SinaisLIBRAS (variante falada pela comunidade surda de Brasília) com a Língua Portuguesa e suas implicações no ensino de Português, como segunda Língua, para surdos". Revista Pesquisa Linguística, Brasília: LIV/UNB, fascículo 6, série 2, 3-12.

(2003). A metáfora na LBS e a construção dos sentidos no desenvolvimento da competência comunicativa de alunos surdos. Brasília: Universidade de Brasília. 304p. (Dissertação - Mestrado) - Programa de Pós-graduação em Linguística. Brasília.

(2002). "Cultura Surda e Cidadania Brasileira”. In: SALLES, Heloisa Maria Moreira Lima et. al. Ensino de língua portuguesa para surdos: caminhos para a prática pedagógica 1, Brasília: SEESP/MEC.

FÁVERO, Leonor Lopes (1999). Coesão e coerência textuais. 6.ed. São Paulo: Ática.

; KOCH, Ingedore Villaça (1998). Linguística textual: introdução. 4.ed. São Paulo: Cortez.

KOCH, Ingedore Villaça (1999). A coesão textual. 11.ed. São Paulo: Contexto. 
(2008). As tramas do texto. Rio de Janeiro: Nova Fronteira. (2004). Introdução à linguística textual: Trajetórias e grandes temas. São Paulo: Martins Fontes.

(2009). O texto e a construção do sentido. 9.ed. São Paulo: Contexto.

; TRAVAGLIA. Luiz Carlos (2001). A coerência textual. 12.ed. São Paulo: Contexto.

MARCUSCHI, Luiz Antonio (2008). Produção textual, análise de gêneros e compreensão. São Paulo: Parábola Editorial.

(2005). Da fala para a escrita: atividades de retextualização. São Paulo: Cortez.

QUADROS, Ronice Mülller (1997). Educação de surdos: a aquisição da linguagem. Porto Alegre: Artmed.

; SCHMIEDT, Magali (2006). Idéias para ensinar português para alunos surdos. Brasília: MEC, SEESP.

SALLES, Heloisa Maria Moreira Lima et al (Orgs) (2004). Ensino de língua portuguesa para surdos: caminhos para a prática pedagógica. Brasília: Ministério da Educação.

(2004). Ensino de Língua portuguesa para surdos - Caminhos para a prática pedagógica. Brasília: MEC/SEESP, vol 2.

SAMPAIO, Maria Janaina Alencar (2007). A construção de textos na escrita de surdos: estratégias do sujeito na transição entre sistemas linguísticos. João Pessoa: UFPB. (Dissertação - Mestrado) - Linguagem e Ensino. Universidade Federal da Paraíba.

Mônica de Gois Silva Barbosa é Mestre em Letras, UFS; (3ํ) Graduação Grande área: Linguística, Letras e Artes / Área: Letras / Subárea: Ensino de Línguas: Língua Portuguesa e LIBRAS. Grupo de Estudos e Pesquisas Identidades e Alteridades: Desigualdades e Diferenças na Educação (GEPIADDE); Grupo de Estudo e Pesquisa em Alfabetização, Discurso e Aprendizagem (GEADAS) e Núcleo de Pesquisa Inclusão Escolar da Pessoa com Deficiência (NUPIEPED); Língua Portuguesa como segunda língua para surdos; Atendimento Educacional Especializado. Lattes: http://lattes. cnpq.br/4053462411412764E-mail: monicagsb@yahoo.com.br 
Alzenira Aquino de Oliveira é Mestre em Letras, UFS; Graduação Grande área: Linguística, Letras e Artes / Área: Letras / Subárea: Ensino de Línguas: Língua Portuguesa e LIBRAS. Núcleo de Pesquisa Inclusão Escolar da Pessoa com Deficiência (NUPIEPED); Troféu Piriri (2012) - Superação na Adversidade, Conselho Municipal de Defesa dos Direitos da Pessoa com Deficiência - Aracaju/SE. Lattes: http://lattes.cnpq.br/5923903102053905 E-mail: alzeaquino@yahoo.com.br

Claudio Manoel de Carvalho Correia é Doutor em Comunicação e Semiótica pela PUC-SP. Professor Adjunto da UFS. (3의 Graduação Grande área: Linguística, Letras e Artes / Área: Linguística / Subáreas: Semiótica e Psicolinguística. (4으) Correia, Claudio Manoel de Carvalho. Líder do Grupo de Pesquisa GEMADELE- Elaboração e análise de material didático para ensino de línguas estrangeiras/adicionais da UFS e Membro do Grupo de Pesquisa SELEPROT - Semiótica, Leitura e Produção de Texto da UERJ. Lattes: http://lattes.cnpq.br/9935874859230938. E-mail: claudiomanoelcorreia@gmail.com 